\title{
RELATIONSHIP BETWEEN KINETICS OF GROWTH AND PRODUCTION OF EXO-ELECTRONS: CASE STUDY WITH GEOBACTER TOLUENOXYDANS
}

\author{
ATTILA SZÖLLÖSI*, LÁSZLÓ NARR, \\ AtTila G. KovÁcs and Gabriella StYeVkó \\ Faculty of Food Science, Department of Brewing and Distilling, \\ Corvinus University of Budapest, Menesi út 45, H-1118 Budapest, Hungary
}

(Received: 5 May 2015; accepted: 17 June 2015)

\begin{abstract}
Kinetics of growth and product formation of G. toluenoxydans DSMZ 19350 strain were investigated using sodium-acetate as substrate and $\mathrm{Fe}^{3+}$-ions and fumarate as electron acceptor. Response surface method was adapted for evaluation of growth of bacteria. Results showed that maximum growth was detected in the case of $2.2 \mathrm{~g} / \mathrm{L}$ substrate concentration. Application of higher substrate concentration $(>2.5 \mathrm{~g} / \mathrm{L}$ sodium acetate) significantly inhibits the bacterial growth. Luong's model was found to be the most suitable to determine kinetic parameters $\left(\mu_{\max }=0.0331 / \mathrm{h}\right.$, $\mathrm{K}_{\mathrm{S}}=0.205 \mathrm{~g} / \mathrm{L}$ ) of growth of G.toluenoxydans strain, and the growth was completely inhibited at substrate concentration higher than $3.1 \mathrm{~g} / \mathrm{L}$. In the case of product formation the Haldane model was used and kinetic parameters are $\mu_{\mathrm{P} \max }=0.123$ $\mathrm{mg} / \mathrm{h}, \mathrm{K}_{\mathrm{PS}}=0.184 \mathrm{~g} / \mathrm{L}$. Correlation between microbial growth and product formation was observed using the Luedeking-Piret empirical method. Both factors (growth and number of cells) affected significantly iron(III)-reduction, thus the product formation. These results are important and open the possibility to design a continuous MFC setting operating with $G$. toluenoxydans as biocatalyst.
\end{abstract}

Keywords: iron-reduction, Geobacter toluenoxydans, microbial fuel cell

\section{Introduction}

Recently, the development of new renewable carbon-neutral energy sources has utmost importance [1]. Microbial fuel cell (MFC) technology would be attractive and an economically desirable process because this device enables to produce electricity from different wastewaters while significantly decreasing the organic pollution [2]. Microbial fuel cells are devices that use bacteria as the catalysts and generate electric current through the oxidation of organic and in-

*Corresponding author; E-mail: attila.szollosi@uni-corvinus.hu 
organic matters. Electrons are produced by bacteria from these substrates and transferred to the anode and flow to the cathode linked by a conductive material containing a resistor or a load [3].

Numerous studies reported strong correlation between microbial $\mathrm{Fe}^{3+}$-reduction and extracellular electron-transfer between microbe and MFC anode $[4,5]$, thus a microbe with capability of extending extracellular iron(III)-reduction is very promising in MFC application.

Members of Geobacteraceae (G. sulfurreduces [6], G. metallireducens [7]) are frequently applied as bio-catalyst in MFC systems [8], however scientific data of the physiology of Geobacter species are still lacking [9]. The exo-electron producing properties of these microorganisms are very impressive, however the substrate utilization capability is limited and varied depending on carbohydrates and organic acids [10]. Geobacter toluenoxydans was first isolated from tar-oil contaminated sludge in Stuttgart, Germany. The place of isolation indicates an unusual metabolism of the microbe. G. toluenoxydans is known as an obligate anaerobic Gram-negative, non-spore-forming, non-motile, straight rods, 2.1$3.8 \mathrm{~mm}$ long and $0.4 \mathrm{~mm}$ wide, iron-reducing bacterium. It is able to utilize ferrihydrite, ferric citrate and fumarate as electron acceptors combined with acetate as electron donor. However this bacterium does not reduce Mn(IV), nitrate, sulphate, sulphite, thiosulphate or sulphur, but it has the ability to utilize monoaromatic compounds such as toluene, benzyl-alcohol, benzaldehyde, phenol, m- and p-cresol as electron donor [11]. Moreover, our previous experiments (unpublished data) show that this microbe exhibited significantly higher $\mathrm{Fe}^{3+}$-reduction rate than other examined Geobacter species (G. sulfurreducens, G. metallireducens, G. lovley), thus it has potential application in the bioremediation as well as in microbial fuel cell (MFC) systems as a bio-catalyst. So far, only little scientific information is available in literature dealing with the application of this organism.

Present study reveals the growth and exo-electron production properties of $G$. toluenoxydans in media containing different sodium-acetate concentration. In this sense the microbial growth properties as well as reducing capability and correlation of these features are evaluated.

\section{Materials and Methods}

\section{Cell culturing conditions}

Geobacter toluenoxydans DSMZ 19350 strain was purchased from Leibniz Institute DSMZ-German Collection of Microorganisms and Cell Cultures 
(Germany) and inoculated at $30{ }^{\circ} \mathrm{C}$ in anaerobic condition. The growth medium contained the following mineral salts: $\mathrm{NaHCO}_{3} 2.5 \mathrm{~g} / \mathrm{L} ; \mathrm{NH}_{4} \mathrm{Cl} 0.25 \mathrm{~g} / \mathrm{L}$; $\mathrm{NaH}_{2} \mathrm{PO}_{4} \cdot \mathrm{H}_{2} \mathrm{O} 0.06 \mathrm{~g} / \mathrm{L} ; \mathrm{KCl} 0.1 \mathrm{~g} / \mathrm{L}$; and was supplemented with a trace mineral (DSMZ trace element solution SL-10) and vitamin solutions (DSMZ medium 141). Sodium acetate $(1 \mathrm{~g} / \mathrm{L})$ was used as electron donor, and either sodium-fumarate $(5 \mathrm{~g} / \mathrm{L})$ or ferric-citrate $(5 \mathrm{~g} / \mathrm{L})$ as electron acceptor. The medium was sealed with liquid paraffin to omit the contact with oxygen. After the paraffin addition the mixture, except the vitamin solution, was sterilized by autoclaving for 20 min at $121{ }^{\circ} \mathrm{C}$ to expel the residual oxygen from the solution. For analysis an inoculum with cell count of $10^{6}-10^{7} \mathrm{CFU} / \mathrm{mL}$ was used.

\section{Determination of growth kinetics}

To analyse the growth of microorganism broths containing different amount of sodium-acetate $0.5 \mathrm{~g} / \mathrm{L}$ to $3 \mathrm{~g} / \mathrm{L}$ in steps of $0.5 \mathrm{~g} / \mathrm{L}$ were used. The microbial propagation was followed by optical density measurement at wavelength of $600 \mathrm{~nm}$. The cell counts were calculated from the absorbance values through the relation of absorbance and pour-plated cell counts. From the calculated cell count the growth curves were plotted. Kinetic parameters of growth of bacteria were calculated based on growth curves. Each experimental run was simultaneously carried out in triplicates in three independent MFC units to confirm the reproducibility and reliability of the results.

\section{Determination of kinetics of product formation}

To evaluate the microbial reduction of iron(III) ions, various broths containing different concentration of sodium acetate were applied. These broths were supplemented with $\mathrm{Fe}(\mathrm{III})$-citrate as electron acceptor in oversaturation $(5 \mathrm{~g} / \mathrm{L})$. The oxygen was excluded with liquid paraffin on the fluid surface. The cultivation was carried out in incubator at $30^{\circ} \mathrm{C}$.

Samples were taken daily up to 126 hours of fermentation. The $\mathrm{pH}$ of samples was adjusted to 2 with cc. sulphuric acid and was supplied with ammoniumthiocyanate $\left(\mathrm{NH}_{4} \mathrm{SCN}\right)$ as a colouring agent in oversaturation $(50 \mathrm{~g} / \mathrm{L})$. The final dilution rate of the sample was 200. After rigorous mixing, the absorbance was measured at wavelength of $460 \mathrm{~nm}$ by spectrophotometer [12]. 


\section{Results and Discussion}

Effects of sodium acetate on growth kinetics of $G$. toluenoxydans

The growth properties of Geobacter toluenoxydans were studied using sodium-acetate as substrate. Different media contained sodium-acetate in concentration from $0.5 \mathrm{~g} / \mathrm{L}$ up to $3 \mathrm{~g} / \mathrm{L}$ were prepared and after inoculation of bacteria. Response surface method was applied to evaluate the results and cell counts were plotted against culturing time and concentration of sodium acetate (Fig. 1). Increase in sodium-acetate concentration up to $2.0 \mathrm{~g} / \mathrm{L}$ affect a relevant enumeration of cell count. In this case, maximum cell counts in stationer phase were 9.1 $10^{7} \mathrm{CFU} / \mathrm{mL}$. The maximum specific growth rates as well as generation times were calculated in range of $0.005-0.0371 / \mathrm{h}$ and of $18-138 \mathrm{~h}$, respectively. EsteveNúñez et al. [9] studied the growth of $G$. sulfurreducens in continuous condition and found that the biomass productivity was linear at dilution rate of 0.04-0.09 $1 / \mathrm{h}$ meaning the specific growth rate of $0.04-0.091 / \mathrm{h}$. Moreover, acetate as substrate does not inhibit the growth of G. sulfurreducens, whereas in our case, the increase in sodium-acetate (higher than $2.0 \mathrm{~g} / \mathrm{L}$ concentration) inhibited the microbial growth. It may explain the differences of the two species [11].

Due to repression effect of the substrate, the conventionally applied Monodkinetics is not suitable to describe correctly the growth kinetics of G. toluenoxydans, thus other kinetic model (modified Monod model) was tested. In our case, Luong's model [13] has been applied for evaluation of results.

$$
\mu=\mu_{\max } \times \frac{S}{K_{S}+S}\left(1-\frac{S}{S_{\max }}\right)^{n}
$$

where, $\mu$ is the specific growth rate, $\mu_{\max }$ is the maximal growth rate, $\mathrm{S}$ is the substrate concentration, $\mathrm{K}_{\mathrm{S}}$ is the Monod constant, $\mathrm{S}_{\max }$ is the maximal substrate concentration at which specific growth rate is zero, $\mathrm{n}$ is a constant.

This model is based on Monod model with implementation of the inhibition effects.

The built model is illustrated in Fig. 2.

Using this model, the following kinetic constants were calculated:

$\mu_{\max }=0.0331 / \mathrm{h}$,

$\mathrm{K}_{\mathrm{S}}=0.205 \mathrm{~g} / \mathrm{L}$,

$\mathrm{n}=1.1$,

$\mathrm{S}_{\max }=3.10 \mathrm{~g} / \mathrm{L}$.

The estimated maximal growth rate of $G$. toluenoxydans is similar to ones $\left(\mu_{\max }=0.01-0.091 / \mathrm{h}\right)$ of other Geobacter strains [9]. It is well known that the Geobacter strains are characterized as a "slow growing" microorganisms [9], thus in 


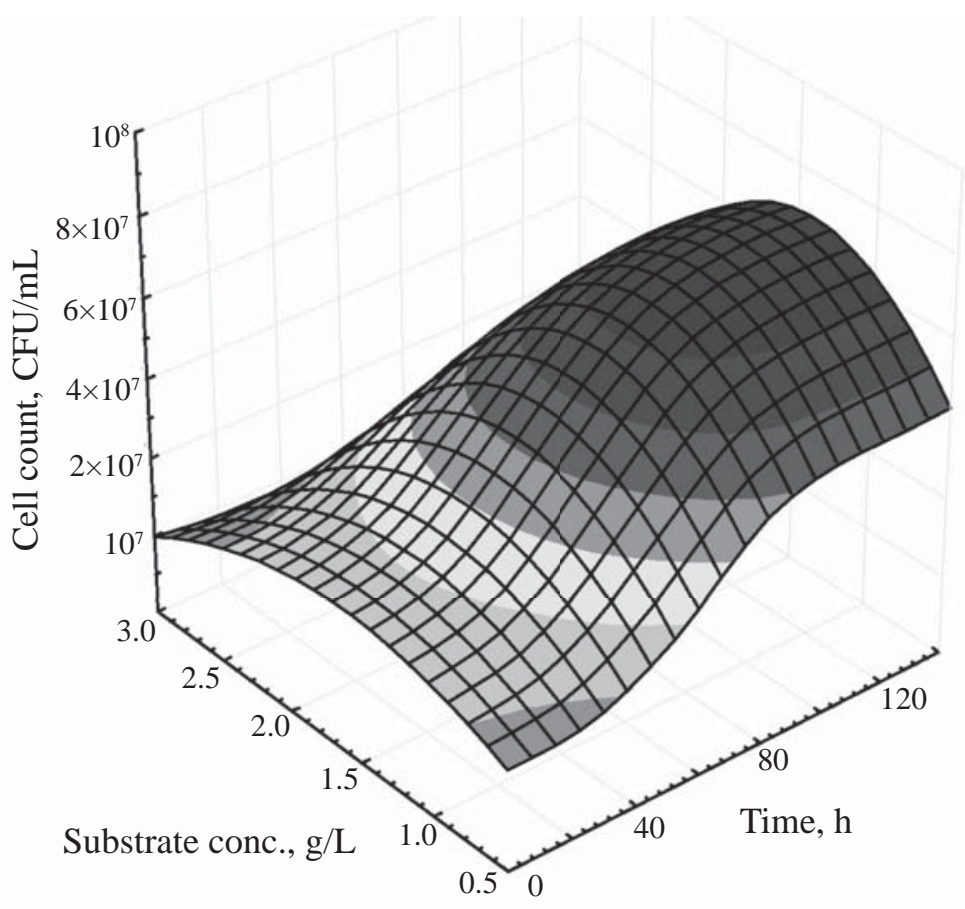

Figure 1. Growth curves of G. toluenoxydans in different Na-acetate containing nutrient broths

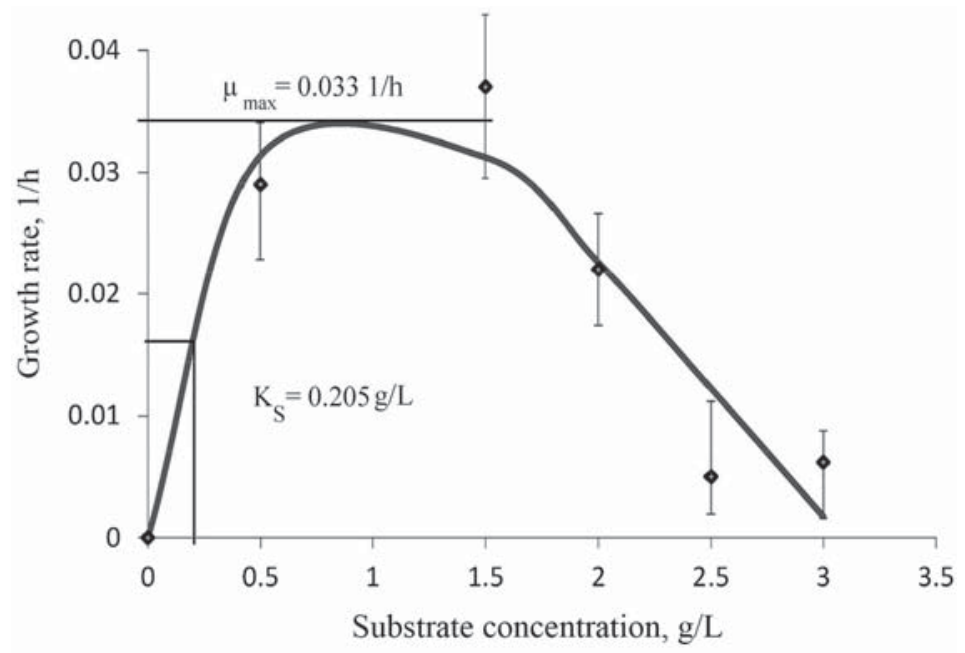

Figure 2. Modelling of growth rate related to substrate concentration 
practical application culture condition optimization methods [14-16] are required to enrich the bacterial cells for further applications. According to our model, addition of $3.1 \mathrm{~g} / \mathrm{L}$ sodium-acetate concentration totally inhibited the microbial growth. It is in agreement with results presented in Fig. 1. Interestingly, in the case of Geobacter species, inhibition kinetics has not been reported yet.

\section{Kinetics of product formation}

In the previous studies [4, 12], strong correlation between microbial iron(III)-reduction and exo-electron production was demonstrated. Based on this theory the microbial iron-reduction can be classified as product formation. In the case of $1.5 \mathrm{~g} / \mathrm{L} \mathrm{Na}$-acetate as substrate concentration, product formation (change of absorbance at $460 \mathrm{~nm}$ ) was showed in Fig. 3. Comparing two curves (growth and formation of product), significant differences were observed. Generally, the lag-phase takes about 24-30 hours from the beginning of the cultivation and then it was followed by the exponential phase up to 80 hours and stationer phase. In the lag-phase and up to half of the exponential phase (50 hours), product formation was detectable, but the reduction rate was quite low. Intensive product formation was observed after 50 hours and it continued to the end of the cultivation. It means that the production of exo-electrons does not completely associate to growth of bacterial cells.

Numerous models were used to determine kinetic parameters of product formation, but only the Haldane model [17] proved to be suitable to describe the $\mathrm{Fe}^{3+}$-reduction of $G$. toluenoxydans. The complete model is following:

$$
\mu^{P}=\mu_{\text {max }}^{P} \times \frac{S}{\left(S+K_{S}\right)\left(\frac{S}{K_{S I}}\right)}
$$

Where, $\mu^{\mathrm{P}}$ : specific $\mathrm{Fe}^{3+}$-reduction rate, $\mathrm{mg} / \mathrm{h} ; \mu_{\text {max }}^{\mathrm{P}}$ : maximal $\mathrm{Fe}^{3+}$-reduction rate, $\mathrm{mg} / \mathrm{h} ; \mathrm{S}$ : substrate concentration, $\mathrm{g} / \mathrm{L} ; \mathrm{K}_{\mathrm{S}}$ : Monod-constant, $\mathrm{g} / \mathrm{L} ; \mathrm{K}_{\mathrm{SI}}$ : substrate inhibition constant, $\mathrm{g} / \mathrm{L}$.

The regressed model is illustrated in Fig. 4.

Based on this model the following kinetic constants were calculated: $\mu_{\text {max }}^{\mathrm{P}}=0.1231 / \mathrm{h}, \mathrm{K}_{\mathrm{S}}=184 \mathrm{~g} / \mathrm{L}, \mathrm{K}_{\mathrm{SI}}=1.104 \mathrm{~g} / \mathrm{L}$.

The maximum iron(III)-reducing rate of G. toluenoxydans was $0.123 \mathrm{mg}$ $\mathrm{Fe}^{3+} / \mathrm{h}$ at $1 \mathrm{~g} / \mathrm{L}$ sodium acetate as substrate concentration. The Haldane model also provides information about the substrate concentration where the microbial iron-reduction becomes to be inhibited. In the case of G. toluenoxydans DSMZ 19350 strain the inhibition substrate concentration was $1.104 \mathrm{~g} / \mathrm{L} \mathrm{Na-acetate.}$ 


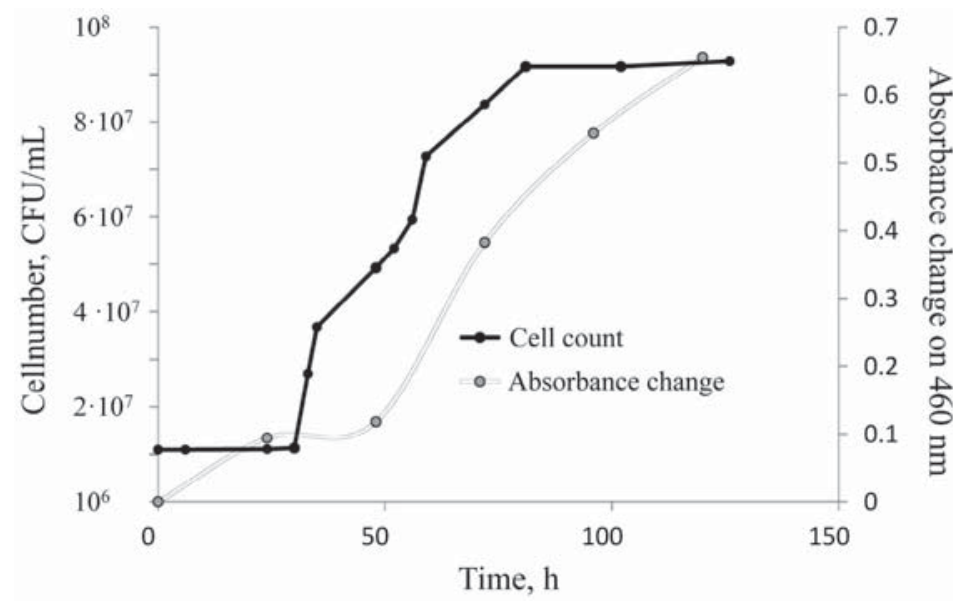

Figure 3. Iron(III)-reduction and growth curves of G. toluenoxydans

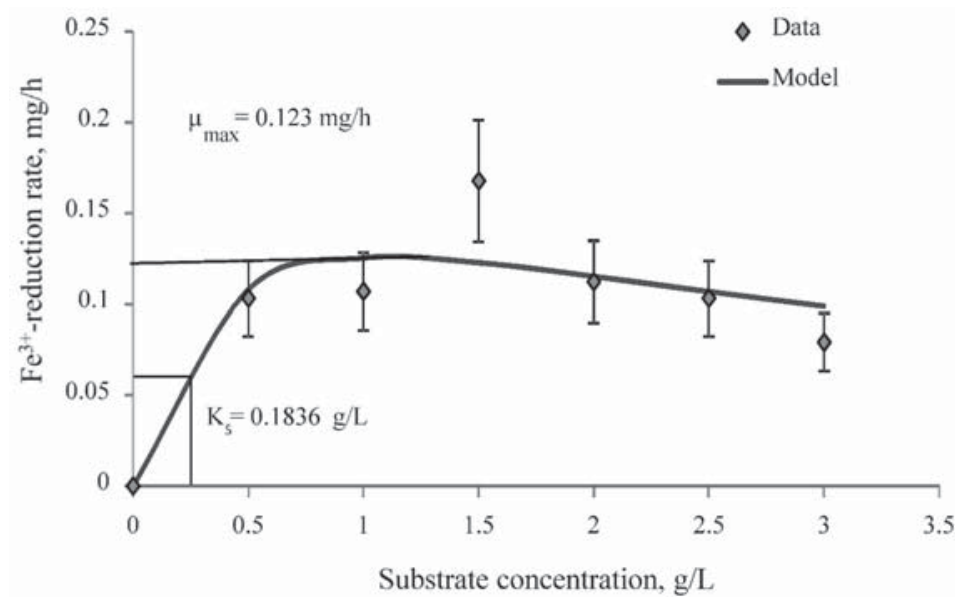

Figure 4. Modelling of iron(III)-reduction rate related to substrate concentration of G. toluenoxydans

\section{Relationship between the microbial growth and product formation}

The method of Luedeking and Piret [18] was applied for evaluation of relationship of the microbial growth and iron(III)-reduction capability. The $\mathrm{Fe}^{3+}$-reduction rates were graphically plotted against the values of growth rates (Fig. 5).

The slope of the fitted line is 1.838 which is definitely greater than zero that indicates a strong correlation between microbial growth and iron-reduction. However the intersection of ordinate is also not zero, suggested the effect 


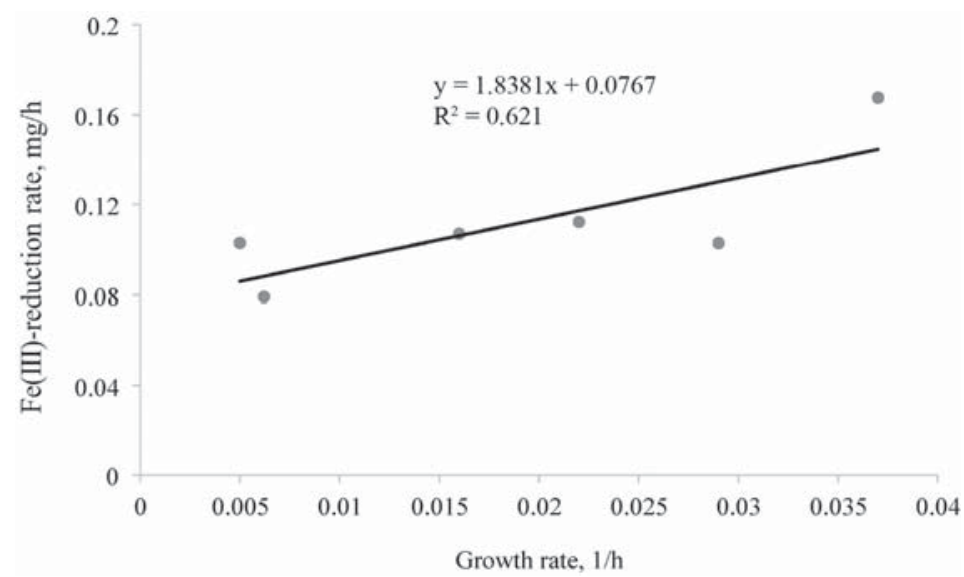

Figure 5. Connection between microbial growth and iron(III)-reduction rate of $G$. toluenoxydans

of instantaneous cell number on $\mathrm{Fe}^{3+}$-reduction. Assuming the result of the analysis both microbial growth and cell mass have relevant effect on iron-reduction. These results open possibility to design a continuous MFC setting operating with G. toluenoxydans.

\section{Conclusions}

G. toluenoxydans DSMZ 19350 strain was grown well in medium containing sodium-acetate as substrate and $\mathrm{Fe}^{3+}$-ions as electron acceptor. Due to inhibition effect of substrate the classical Monod model was not suitable to determine kinetic parameters of both growth and product formation, instead the Luong and Haldane models should be applied. The intensive production of exo-electron by this strain is generally started from the middle of exponential phase. Over-supplementation of sodium-acetate significantly decreases both growth and $\mathrm{Fe}^{3+}$-reduction. Product formation is strongly depending on microbial growth (growth rate) and biomass level (cell count) in the bioreactor. These results are essential scientific data for development of MFC systems using G. toluenoxydans as biocatalyst for treatment of wastewaters. 


\section{Acknowledgements}

This work is supported by National Development Agency (Project no. TÁMOP-4.2.1./B-09/1-KMR-2010-0005, TÁMOP-4.2.2/B-10/1-2010-0023 and TECH_09-A3-2009-0194), as well as the Bolyai Research Grant from the Hungarian Academic of Sciences. Authors would like to thank Dr. Quang Nguyen Duc Professor at the Department of Brewing and Distilling, Corvinus University of Budapest for creating the manuscript.

\section{Conflict of Interest}

None.

\section{References}

1. Demirbas, A. H., Demirbas, I.: Importance of rural bioenergy for developing countries. Energy Conv Manag 48, 2386-2398 (2007).

2. Herrero-Hernandez, E., Smith, T. J., Akid, R.: Electricity generation from wastewaters with starch as carbon source using a mediatorless microbial fuel cell. Biosens Bioelectron 39, 194-198 (2013).

3. Logan, B. E., Hamelers, B., Rozendal, R. A., Schrorder, U., Keller, J., Freguia, S., Aelterman, P., Verstraete, W., Rabaey, K.: Microbial fuel cells: Methodology and technology. Environ Sci Technol 40, 5181-5192 (2006).

4. Feng, C. H., Yue, X. J., Li, F. B., Wei, C. H.: Bio-current as an indicator for biogenic $\mathrm{Fe}(\mathrm{II})$ generation driven by dissimilatory iron reducing bacteria. Biosens Bioelectron 39, 51-56 (2013).

5. Lovley, D. R.: Long-range electron transport to Fe(III) oxide via pili with metallic-like conductivity. Biochemical Society Transactions 40, 1186-1190 (2012).

6. Bond, D. R., Lovley, D. R.: Electricity production by Geobacter sulfurreducens attached to electrodes. Appl Environ Microbiol 69, 1548-1555 (2003).

7. Reguera, G., McCarthy, K. D., Mehta, T., Nicoll, J. S., Tuominen, M. T., Lovley, D. R.: Extracellular electron transfer via microbial nanowires. Nature 435, 1098-1101 (2005).

8. Debabov, V. G.: Electricity from microorganisms. Microbiology 77, 123-131 (2008).

9. Esteve-Núñez, A., Rothermich, M., Sharma, M., Lovley, D.: Growth of Geobacter sulfurreducens under nutrient-limiting conditions in continuous culture. Environ Microbiol 7, 641-648 (2005).

10. Pant, D., Van Bogaert, G., Diels, L., Vanbroekhoven, K.: A review of the substrates used in microbial fuel cells (MFCs) for sustainable energy production. Bioresource Technology 101, 1533-1543 (2010).

11. Kunapuli, U., Jahn, M. K., Lueders, T., Geyer, R., Heipieper, H. J., Meckenstock, R. U.: Desulfitobacterium aromaticivorans sp nov and Geobacter toluenoxydans sp nov., ironreducing bacteria capable of anaerobic degradation of monoaromatic hydrocarbons. Int J Syst Evol Microbiol 60, 686-695 (2010). 
12. Szöllősi, A., Rezessy-Szabó, J. M., Hoschke, Á., Nguyen, Q. D.: Novel method for screening microbes for application in microbial fuel cell. Bioresource Technology 179, 123-127 (2015).

13. Luong, J. H. T.: Generalization of Monod kinetics for analysis of growth data with substrate-inhibition. Biotechnol Bioeng 29, 242-248 (1987).

14. Coppi, M. V., Leang, C., Sandler, S. J., Lovley, D. R.: Development of a genetic system for Geobacter sulfurreducens. Appl Environ Microbiol 67, 3180-3187 (2001).

15. Lovley, D. R., Phillips, E. J. P.: Novel mode of microbial energy-metabolism - Organiccarbon oxidation coupled to dissimilatory reduction of iron or manganese. Appl Environ Microbiol 54, 1472-1480 (1988).

16. Kim, M. S., Lee, Y. J.: Optimization of culture conditions and electricity generation using Geobacter sulfurreducens in a dual-chambered microbial fuel-cell. International Journal of Hydrogen Energy 35, 13028-13034 (2010).

17. Haldane, J. B. S.: Union of enzymes with substrate. In Reder, W. D. (ed.): Enzymes, 1st Edition. Longmans, Green \& Co., London, 1930, pp. 28-53.

18. Luedeking, R., Piret, E. L.: A kinetic study of the lactic acid fermentation. Batch process at controlled pH. J Biochem Microbiol 1, 393-412 (1959). 